\title{
Modelling of sedimentation processes inside Roseires Reservoir (Sudan)
}

\author{
A. Y. A. Omer ${ }^{1,2}$, Y. S. A. Ali ${ }^{1,3}$, J. A. Roelvink ${ }^{1,4}$, A. Dastgheib ${ }^{1}$, P. Paron ${ }^{1}$, and A. Crosato ${ }^{1,5}$ \\ ${ }^{1}$ UNESCO-IHE, Westvest 7, 2601 DA Delft, the Netherlands \\ ${ }^{2}$ Dams Implementation Unit of Ministry of Water Resources and Electricity, P. O. Box 12843, Mashtal Street, \\ Riyadh District, Quarter No. 16 Khartoum, Sudan \\ ${ }^{3}$ Ministry of Water Resources and Electricity, Hydraulic Research Station, Wad Madani, Sudan \\ ${ }^{4}$ Deltares, Rotterdamseweg 185, Delft, the Netherlands \\ ${ }^{5}$ Delft University of Technology, Faculty of Civil Engineering and Geosciences, Delft, the Netherlands
}

Correspondence to: Y. S. A. Ali (yasir_hrs@hotmail.com)

Received: 27 September 2013 - Published in Earth Surf. Dynam. Discuss.: 18 March 2014

Revised: 28 February 2015 - Accepted: 11 March 2015 - Published: 2 April 2015

\begin{abstract}
Roseires Reservoir, located on the Blue Nile River in Sudan, is the first trap to the sediments coming from the vast upper river catchment in Ethiopia, which suffers from high erosion and desertification problems. The reservoir has already lost more than one-third of its storage capacity due to sedimentation in the last four decades. Appropriate management of the eroded soils in the upper basin could mitigate this problem. In order to do that, the areas providing the highest sediment volumes to the river have to be identified, since they should have priority with respect to the application of erosion control practices. This requires studying the sedimentation record inside Roseires Reservoir in order to assess when and how much sediment is deposited and to identify its source. This paper deals with the identification of deposition time and soil stratification inside the reservoir, based on historical bathymetric data, numerical modelling and newly acquired soil data. The remoteness of the study area and the extreme climate result in coring campaigns being expensive and difficult. Therefore, these activities need to be optimised and coring locations selected beforehand. This was done by combining bathymetric data and the results of a depth-averaged morphodynamic model recording the vertical stratification in sediment deposits. The model allowed for recognising the areas that are potentially subject to neither net erosion nor bar migration during the lifespan of the reservoir. Verification of these results was carried out by analysing sediment stratification from the data collected during the subsequent field campaign.
\end{abstract}

\section{Introduction}

The construction of dams and reservoirs represents a great achievement for the management of the water resource, but at the same time it creates a relevant disturbance to the river ecology and morphology. Nevertheless, reservoirs are built for a number of reasons, such as hydropower, irrigation, drinking water supply and flood mitigation (Rãdoane and Rãdoane, 2005). Unfortunately, reservoirs have a limited life, mainly due to sedimentation (White, 2001). Sedimentation not only decreases the lifespan of the reservoir but also changes the river morphology in the downstream and upstream parts of the river. In addition, the settling of river sediment in reservoirs can have important implications for the riverine ecosystem and the coastal development downstream of the dam (de Vente et al., 2005; WCD, 2000). Therefore, it is vital to study and predict the sediment yield at the basin scale and realise which factors determine the sedimentation rate of reservoirs. This knowledge allows for effective measures to be taken against reservoir sedimentation, water shortage, and erosion of coast and river banks. Sedimentation processes in reservoirs have been addressed by many authors, e.g. Duquennois (1956), Borland (1971), Bowonder et al. (1985), Mohmood (1987), Annandale (1987), Hotchkiss and Parker (1991), Fan and Morris (1992), Sloff (1997) and 


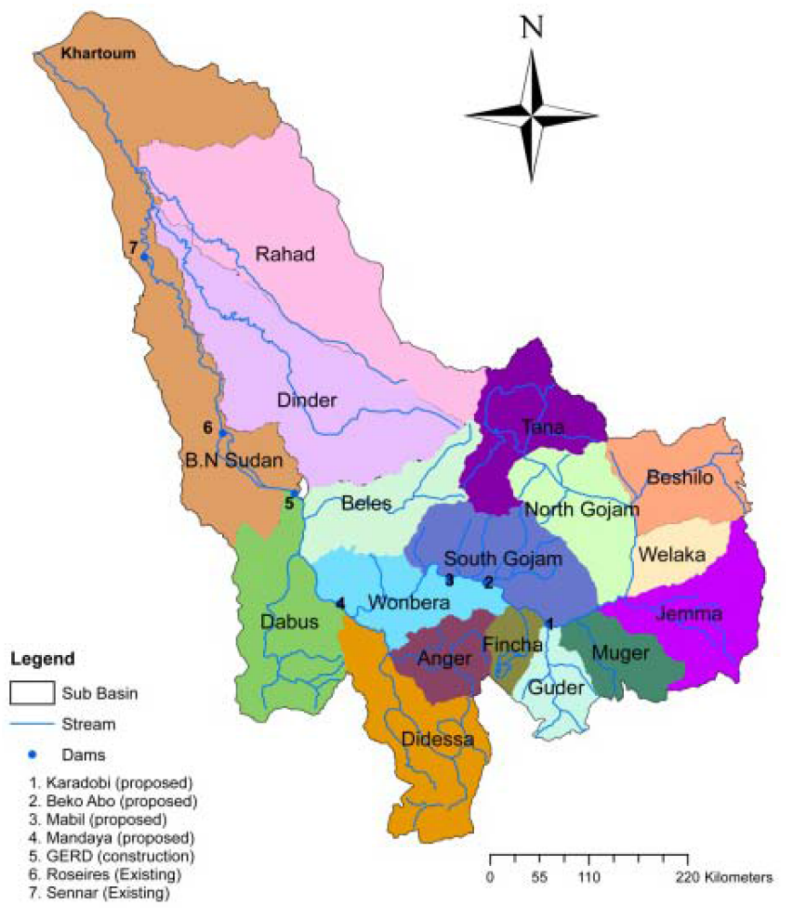

(a)

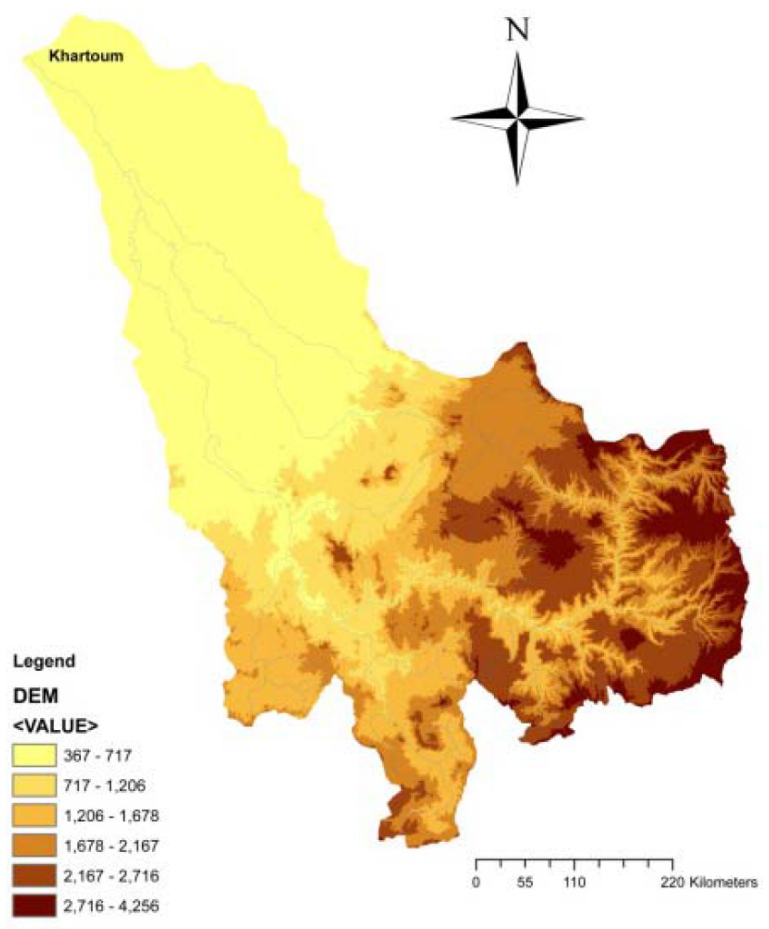

(b)

Figure 1. Blue Nile Basin and Roseires Dam. The elevation map was derived from STRM (90 m) and is in ma.s.1. (WGS84 datum).

White (2001), among many others. In recent years, many experimental and numerical research studies in this field have been pursued all over the world (e.g. Toniolo and Parker, 2003; Hu et al., 2010).

Roseires Reservoir is located on the Blue Nile River, in Sudan (Fig. 1a). It is the first trap to the sediments coming from the upper catchment in Ethiopia, which suffers from high erosion and desertification problems. The reservoir has already lost more than one-third of its storage capacity due to sedimentation in the last four decades. This is a large economic loss to Sudan, in addition to the high maintenance costs of sediment clearance in front of the turbines to facilitate hydropower production. This problem could be mitigated by appropriate management of the upper catchment, where the sediment is coming from. Given the vastness and the remoteness of the region involved, and the extension of the soil erosion problem, the areas providing the highest sediment volumes to the river should be identified first. These areas should then have priority with respect to the application of erosion control practices.

Sedimentation inside reservoirs is influenced by many factors, but primarily it is dependent upon the sediment fall velocity, the water flow through the reservoir and the reservoir operation (Gottschalk, 1964). Due to the complexity and interaction of many parameters, there are no di- rect analytical solutions to predict the reservoir sedimentation rates. Most of the available methods are therefore either empirical models, derived from historical data and information from other reservoirs, or mathematical or physical models (Hama, 2006). The empirical methods are used mostly during the design phase of the reservoir, such as the area reduction method (Annandale, 1987; Borland and Miller, 1958). Other empirical methods include the Brune method (1953), the Churchill method (1948) and the Brown method (1953) (Cristofano, 1953; Bashar et al., 2010; Garg and Jothiprakash, 2008). Numerical models are increasingly used to study the sedimentation process inside reservoirs (e.g. Toniolo and Parker, 2003; Hu et al., 2010).

Unfortunately, to identify the causes of the observed high sedimentation rates inside Roseires Reservoir, empirical methods are not effective. For this, it is necessary to locate the area of origin of the sediment, from the mineralogical analysis of the deposited sediment and from the assessment of the time elapse between the moment the sediment is eroded and the moment the sediment is deposited. This is essential information to identify the cause of soil erosion, for instance by comparing land use maps, for which it is necessary to consider the right timing. All this requires expensive coring campaigns in the upper catchment and inside the reservoir, which need to be optimised. In particular, sediment 
deposition can only be studied at locations inside the reservoir where neither soil erosion nor the movement of bars, reworking the bed sediment, occur. Moreover, at the coring locations, the type of soil stratification should allow for different depositional years to be identified.

In long and narrow reservoirs, like Roseires, the bathymetric profile commonly associated with delta deposits may be absent, but an area characterised by a rapid shift in grain size may mark the downstream limit of coarse material deposition (Morris and Fan, 2009; Vanoni, 2006; Chang and Hill, 1977; Chang, 1982; Hama, 2006). As explained by Morris and Fan (2009), most coarse sediment is delivered to reservoirs by high water flows. The irregular nature of sediment delivery may be recorded in reservoir deposits as alternating layers of coarse and fine sediment. Typically, lenses of sand delivered during high inflow are embedded between layers of fines deposited during periods of low flow. Seasonal discharges may produce regular sequences of strata. In continuously depositional areas, these sediment sequences may be interpreted to reconstruct the depositional history of the reservoir.

In Roseires Reservoir, the use of the same operation rules (release of turbid water and storing of clean water) since the first impounding in 1966, together with the presence of a clear high-flow season and of both sand and fine sediment in the Blue Nile River, may indeed result in clear soil layering in certain parts of the reservoir. The idea is that sand settles inside the reservoir during the high-flow season, when turbid water is released, while fine sediment is deposited mainly during the low-flow season, when all gates are set at the highest level.

To substantiate this, we carried out a preliminary coring campaign inside the reservoir, in an area becoming dry at the end of the low-flow season, close to the dam. The grain size distribution of the sediment, determined at intervals of $30 \mathrm{~cm}$ from the bed surface from a $3.9 \mathrm{~m}$ deep trench, showed that soil layering could be recognised from the analysis of the vertical variation of the sediment $D_{90}$. The coring location ((the coordinates system is UTM, WGS84, Zone 36N), however, appeared subject to erosion, which made it impossible to use those data for the study of historical deposition. Moreover, at that specific location the deposited sediment is mainly sand, most probably settling only during the highflow seasons, which does not allow for the yearly sequences of deposition to be recognised. This preliminary field campaign showed the necessity of returning to the field, but this time only after having identified the best coring locations. This would maximise efficiency and minimise costs, considering that the area is difficult to access and that coring can be carried out only at the end of the low-flow season, when large parts of the reservoir bed become dry.

In order to identify the most promising coring locations inside Roseires Reservoir, we simulated the evolution of the bed topography of the reservoir since 1985 with a physicsbased quasi-three-dimensional morphodynamic model, using the time series of the discharge entering the reservoir. The model computed and recorded the fate of incoming sand and silt, the time variations of the bed level, and the horizontal and vertical variations of soil composition. With this tool, we explored the trends of sedimentation of sand and silt with time inside the entire reservoir. The model allowed recognising the presence of soil stratification in certain areas and the locations where soil erosion is absent, which resulted in the identification of two promising coring locations.

We then returned to the field to study the reservoir soil at the identified locations. This allowed us to study the sediment depositing in the reservoir and gave a unique opportunity to validate the model.

\section{Background information}

\subsection{The Blue Nile River}

The Blue Nile is the main tributary of the Nile River. It originates at the outlet of Lake Tana and flows for nearly $900 \mathrm{~km}$ through Ethiopia before reaching the Sudanese border. In Ethiopia, the Blue Nile has 14 major tributaries (Fig. 1a), which represent the majority of the estimated annual flow of the river, which is $46.2 \times 10^{9} \mathrm{~m}^{3} \mathrm{yr}^{-1}$. Here, the river falls from $1800 \mathrm{~m}$ above sea level at Lake Tana to about $490 \mathrm{~m}$ above sea level at the Sudan border, which gives an averaged longitudinal slope of $1.5 \mathrm{~m} \mathrm{~km}^{-1}$ (Fig. 1b). The upper basin suffers from high erosion problems due to intensive land use and upper catchment desertification and delivers huge quantities of sediment to the river system (Ayalew and Yamagishi, 2004). After leaving Ethiopia, the Blue Nile runs through Sudan for about $735 \mathrm{~km}$ to Khartoum, where it joins the White Nile to form the Nile River. Presently, the Blue Nile waters encounter two dams: the Roseires Dam and the Sennar Dam (Fig. 1a), both in Sudan, but a new dam is currently under construction in Ethiopia, the Grand Renaissance Dam, and other dams are planned.

The slope from the Ethiopian border to Khartoum is 1 order of magnitude milder than in the Ethiopian side, only $15 \mathrm{~cm} \mathrm{~km}^{-1}$ (Abdelsalam and Ismail, 2008). The Dindir and Rahad rivers join the Blue Nile downstream of Sennar Dam in Sudan, contributing with an average annual flow of $4 \times 10^{9} \mathrm{~m}^{3} \mathrm{yr}^{-1}$ together.

The flow of the Blue Nile reflects the seasonality of rainfall over the Ethiopian highlands, which can be distinguished in the wet season, from July to October, with maximum flow in August-September and the dry season, from November to June. Consequently, the annual Blue Nile hydrograph at the Ethiopia-Sudan border has a bell-shape pattern. The daily flow of the river fluctuates between $10 \times 10^{6} \mathrm{~m}^{3}$ in April to $500 \times 10^{6} \mathrm{~m}^{3}$ in August with a ratio of $1: 50$ (Awulachew et al., 2008). 


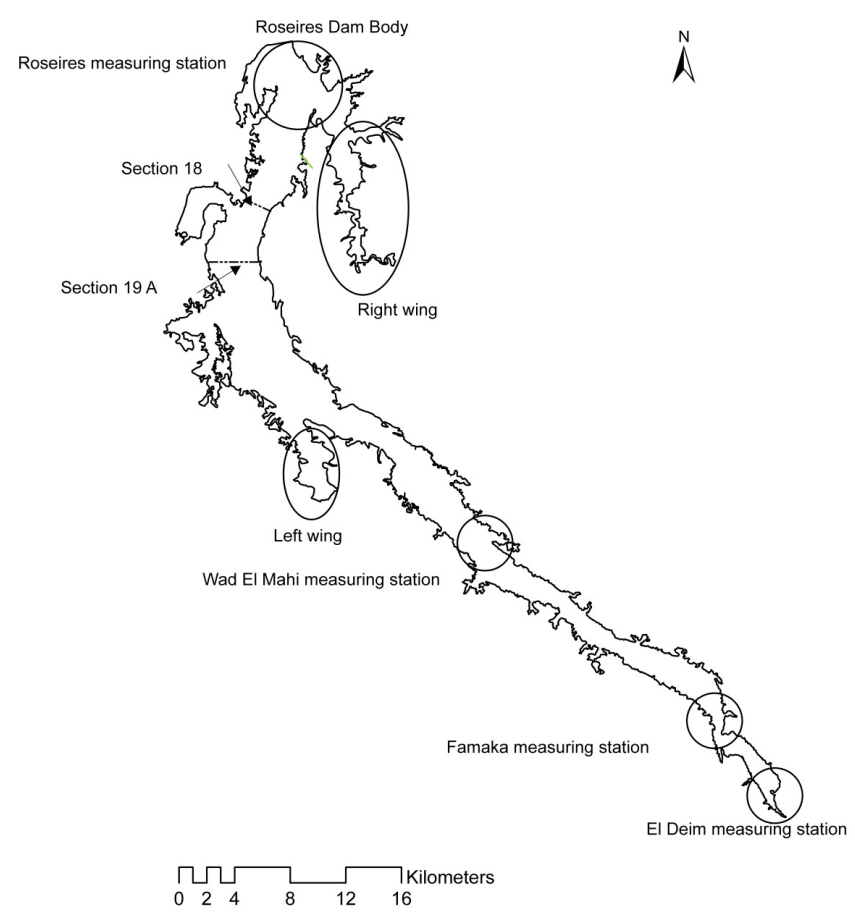

Figure 2. Measurement stations and the areas (circled) that are not covered by the surveys of 1985 and 1992 . The thick black line represents the contour of the reservoir at an elevation of $481 \mathrm{~m}$ a.s.l. (irrigation datum).

\subsection{Roseires Reservoir}

Roseires Reservoir is located in Sudan $550 \mathrm{~km}$ southeast of Khartoum, near the border with Ethiopia (Fig. 1a). It is one of the oldest reservoirs in the basin, since the dam was finalised in 1966 (Fig. 2). This reservoir plays an important role in the economy of Sudan, since it provides hydropower, water for irrigation, and flood control. The maximum length of the reservoir is about $80 \mathrm{~km}$ and the wet area surface is up to $290 \mathrm{~km}^{2}$. The total storage capacity was $3 \times 109 \mathrm{~m}^{3}$ before the first impounding of the reservoir in 1966 (Bashar and Eltayeb, 2010), but in the mean time the reservoir has lost $40 \%$ of this storage capacity due to sediment deposition (Ali, 2014). To limit sedimentation (Sloff, 1997), the gates are kept to the minimum level (open) in the wet season and are raised to the maximum level 1 month before the end of the highflow season and kept so during the dry season (Hussein et al., 2005). During the gate-opening period the water drops by approximately $13 \mathrm{~m}$ and the area surrounding the channel becomes dry. Dredging is carried out every year in front of the power intake. Dredged sediment is dumped in front of the deep sluice gates to be transported away during the flood season, when all the dam gates are open. The process is generally carried out before the flood season (Bashar and Eltayeb, 2010).

To increase the storage capacity of the reservoir, the dam was recently heightened by $10 \mathrm{~m}$ (in 2013). Before height- ening, the full supply level was $481 \mathrm{~m}$ above sea level (irrigation datum) and the minimum supply level of the power generation during flood season was $467.6 \mathrm{~m}$ above sea level (irrigation datum) (Hussein et al., 2005). The bed of the reservoir is cut through by a $10 \mathrm{~m}$ deep channel.

\section{Reservoir sedimentation from bathymetric data}

The reservoir was surveyed in 1976, 1985 (DEMAS, 1985), 1992 (Gismalla, 1993), 2007 (Abd Alla and Elnoor, 2007) and 2009 (Omer, 2011). The bathymetric surveys prior to 2009 do not cover the upstream river reach up to El Deim station, nor the left and right wings of the reservoir (Fig. 3). The bathymetry was measured using an acoustic Doppler current profiler (single beam) and echo-sounders for the wet areas and a differential GPS and survey levels for the temporarily dry areas along specific transects at intervals of $2-5 \mathrm{~km}$ or more in most of the surveys. This low resolution created uncertainty in the generated topographical maps. Moreover, the assessment of the changes in bed elevation was made difficult by the different coordinate systems used and by inaccuracies in the horizontal coordinates. All data were therefore checked, corrected and transformed using the irrigation datum as the reference vertical level.

The local changes in bed level were obtained by comparing the bathymetric data of 20 sections surveyed in 1985 , 1992 and 2007. The resulting temporal variations in storage capacity of Roseires Reservoir are given in Table 1. By subtracting the bed topographies derived from the measured bathymetries, the total storage volume lost in the two periods 1985-1992 and 1992-2007 was quantified as 146 and $238 \times 10^{6} \mathrm{~m}^{3}$, respectively.

The areas with net deposition or erosion were identified by subtracting the bed topography in the two time intervals described above: 2007-1992 and 1992-1985.

\section{Available hydrodynamic and sediment data}

Most data were provided by the Ministry of Irrigation and Water Resources (MoIWR) and the Dams Implementation Unit of the Ministry of Dams and Electricity, Sudan. Figure 2 shows the location of the measuring stations for water levels and sediment concentration inside Roseires Reservoir.

El Deim gauging station for water level, discharge and sediment concentration is located near the Sudan-Ethiopia border. It was established in 1962 during the construction of the dam $110 \mathrm{~km}$ upstream along the river and $85.5 \mathrm{~km}$ linear distance (Fig. 2). The station is situated in a deep rock gorge, which is supposed to provide a very stable control. However, in the last three decades El Deim station has deteriorated and is no longer working properly (Ahmed and Ismail, 2008). 

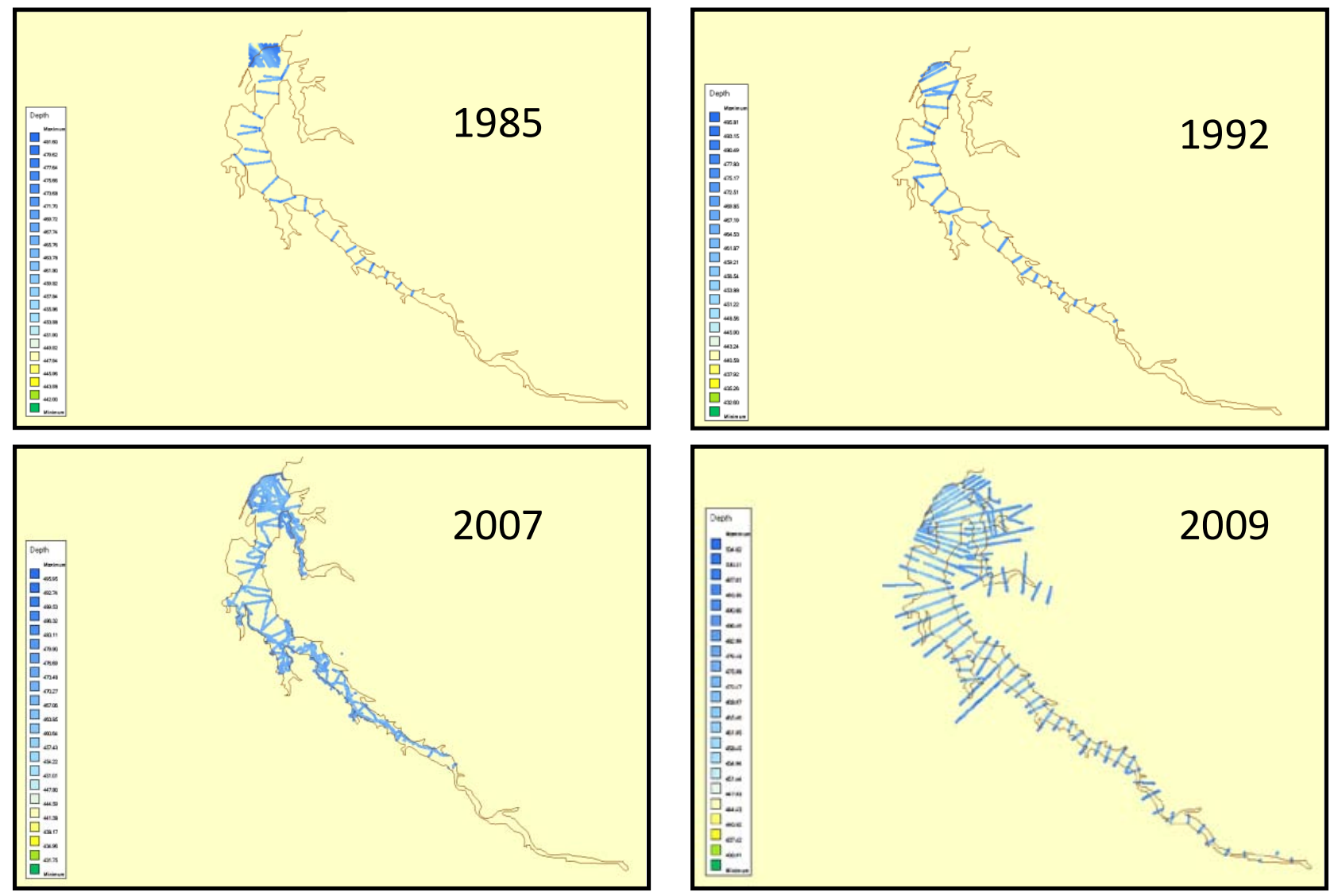

Figure 3. Available bathymetric surveys (cross sections).

Table 1. Storage capacity of Roseires Reservoir in $\times 10^{6} \mathrm{~m}^{3}$ at different years as a function of level, derived from measured bed topographies. ID: irrigation datum

\begin{tabular}{|c|c|c|c|c|c|}
\hline $\begin{array}{l}\text { Level } \\
\text { m a.s.1 } \\
\text { (ID) }\end{array}$ & $\begin{array}{l}\text { Origin (1966) } \\
\text { volume } \\
\left(\mathrm{Mm}^{3}\right)\end{array}$ & $\begin{array}{l}1985 \\
\text { volume } \\
\left(\mathrm{Mm}^{3}\right)\end{array}$ & $\begin{array}{l}1992 \\
\text { volume } \\
\left(\mathrm{Mm}^{3}\right)\end{array}$ & $\begin{array}{l}2007 \\
\text { volume } \\
\left(\mathrm{Mm}^{3}\right)\end{array}$ & $\begin{array}{l}2009 \\
\text { volume } \\
\left(\mathrm{Mm}^{3}\right)\end{array}$ \\
\hline 465 & 452 & 17.13 & 11.9 & 9.05 & 10.88 \\
\hline 467 & 638 & 60.13 & 38.97 & 25.9 & 26 \\
\hline 470 & 991 & 259.2 & 179.8 & 113 & 106.6 \\
\hline 475 & 1821 & 992.8 & 859 & 660.5 & 682.8 \\
\hline 480 & 3024 & 2082 & 1937 & 1701.4 & 1734.7 \\
\hline 481 & 3329 & 2337.6 & 2191.6 & 1953.8 & 1984.7 \\
\hline
\end{tabular}

Water level, discharge and sediment concentration are also available at Famaka at the reservoir inlet; at Wad Almahi inside the reservoir; and at Wad Alies, just downstream of the dam.

The concentration of suspended solids was measured during the flood season at El Deim on a daily basis during the last four decades. The data show a high variability in suspended solids concentrations from year to year and substantial differences between the rising limb and the falling limb of the flood curve (Hussein et al., 2005; Ahmed and Ismail,
2008; Billi and el Badri Ali, 2010; Ahmed et al. 2010). Considering the long-term character of the investigation, in order to represent the historical inputs of suspended solids during the high-flow seasons, we derived the averaged values of suspended solids concentrations from the collected data for three periods: the 1970s-1980s, the 1990s and the 2000s. For the low-flow seasons, due to a lack of historical data, we adopted the averaged sediment concentration of $0.024 \mathrm{~kg} \mathrm{~m}^{-3}$ that we measured during a field campaign in 2011. 


\section{Suspended sediment size in 2002}

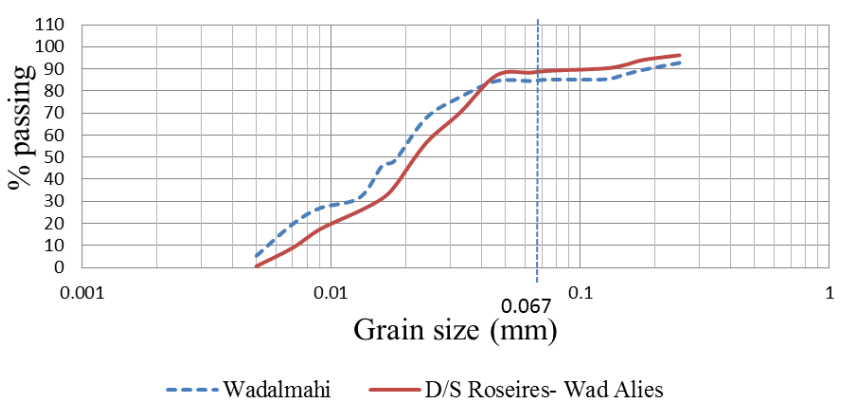

Figure 4. Suspended sediment grain size distributions inside Roseires Reservoir at Wad El Mahi (location in Fig. 2) and downstream of Roseires Dam (source: MoIWR).

The mean diameter of suspended sediment is 18.5 and $22 \mu \mathrm{m}$ at Wad Almahi and Wad Alies, respectively. Silt is the dominant type of sediment in suspension, and it represents more than $80 \%$ of the samples. Sand represents about $15 \%$ of the suspended sediment inside the reservoir (at Wad Almahi) and $10 \%$ of the suspended sediment downstream of the dam (at Wad Alies), as shown in Fig. 4. The analysis of the bed material (Omer, 2011) shows that at some locations sediment contains up to $30 \%$ of silt and clay. Averaging results in a $D_{50}$ of $1200 \mu \mathrm{m}$ upstream of Famaka and a $D_{50}$ of $140 \mu \mathrm{m}$ just upstream of the dam.

\section{Methodology}

Deposition time and soil stratification inside the reservoir are assessed based on the historical bathymetric data, numerical modelling and newly acquired soil data. The study is based on the hypothesis that the alternated stratification of sand and silt reflects the alternation of wet and dry years, respectively.

The analysis of the sediment deposited in the reservoir, however, requires extensive field campaigns, but environmental conditions and economical issues limit the possibility to perform wide-ranging fieldwork. Therefore, field campaigns had to be optimized beforehand, using numerical modelling. For this, field campaigns had to be optimised beforehand.

With the aim of identifying the most promising sampling areas to investigate soil stratification in the reservoir, we combined the analysis of bathymetric data and the results of a morphodynamic model. Data alone allow for areas characterised by net sedimentation to be identified, but these areas might experience periods of erosion in which parts of the layers are lost. Instead, by recording erosion and deposition during the development of the bed topography, the model would allow for the best areas to be recognised. Another advantage of using a numerical model lies in the possibility of better analysing the sedimentation process in Roseires Reservoir, especially if data are scarce and not always reliable, particularly regarding the time evolution.

We adopted a physics-based model that allowed obtaining vertical and horizontal sediment sorting inside the reservoir. The morphodynamic model was constructed using the Delft 3-D software. The setup of the model required two steps: (1) the development of a 2-D depth-averaged hydrodynamic model, and (2) the development of a 2-D morphodynamic model considering two types of sediments - silt and sand according to the two types of sediment transported by the Blue Nile River.

\section{Modelling}

\subsection{Model description}

Lesser et al. (2004) extensively describe the open-source Delft3D code which is applied in the current study (see also http://oss.deltares.nl/web/delft3d).

The hydrodynamic part of the model is based on the 3D Reynolds-averaged Navier-Stokes (RANS) equations for incompressible fluid and water (Boussinesq approximation: Boussinesq, 1903). The closure scheme for turbulence is a $k-\varepsilon$ model, in which $k$ is the turbulent kinetic energy and $\varepsilon$ is the turbulent dissipation. The equations are formulated in orthogonal curvilinear coordinates. The set of partial differential equations in combination with the set of initial and boundary conditions is solved on a finite-difference grid.

We used a 2-D depth-averaged version of the model with an appropriate parameterisation of two relevant 3-D effects of the spiral motion that arises in curved flow (Blanckaert et al., 2003). First, the model corrects the direction of sediment transport through a modification in the direction of the bed shear stress, which would otherwise coincide with the direction of the depth-averaged flow velocity vector. Second, the model includes the transverse redistribution of main flow velocity due to the secondary-flow convection, through a correction in the bed friction term. Taking into account these 3-D effects becomes important not only in curved channels but also in straight channels with bars.

The morphodynamic part of the model simulates the processes of sand (capacity-limited transport) and silt (supplylimited transport) separately. For capacity-limited sediment transport, the evolution of the bed topography is computed from a sediment mass balance equation and a sediment transport formula (Exner approach). A number of capacity-limited transport formulas are available, such as Meyer-Peter and Muller's (1947), Engelund and Hansen's (1967) and van Rijn's (1984). The model accounts for the effects of gravity along longitudinal and transverse bed slopes on bed load direction (Bagnold, 1966; Ikeda, 1982).

For supply-limited transport (fine sediment travelling in suspension), the evolution of the bed topography is computed from the sediment mass balance and an advection-diffusion formulation describing the temporal and spatial evolution 
of suspended solids concentration, coupled to two formulas describing the entrainment and deposition processes. The adopted 2-D (depth-averaged) advection-diffusion equation is

$$
\frac{\partial c}{\partial t}+\frac{\partial u c}{\partial x}+\frac{\partial v c}{\partial y}=\frac{\partial}{\partial x}\left(\varepsilon_{s, x} \frac{\partial c}{\partial x}\right)+\frac{\partial}{\partial y}\left(\varepsilon_{s, y} \frac{\partial c}{\partial y}\right),
$$

where $c$ is the mass (depth-averaged) concentration of the fine sediment fraction $\left(\mathrm{k} \mathrm{m}^{-3}\right)$ and $u$ and $v$ are the flow velocity components in the $x$ and $y$ direction, respectively $\left(\mathrm{m} \mathrm{s}^{-1}\right)$. The velocity and eddy diffusivity $\left(\varepsilon_{s, x, y}\right.$ or $\left.z \varepsilon_{s, x, y}\right)$ components are obtained from the hydrodynamic model.

The following formula (Ariathurai and Arulanandan, 1978; Partheniades, 1964) describes the entrainment of fine sediment from the bed:

$$
E=M\left(\frac{\tau-\tau_{\mathrm{c}}}{\tau_{\mathrm{c}}}\right),
$$

where $E$ is the erosion flux $\left(\mathrm{kg} \mathrm{m}^{-2} \mathrm{~s}^{-1}\right), \tau$ is the bed shear stress $\left(\mathrm{N} \mathrm{m}^{-2}\right)$ and $\tau_{\mathrm{c}}$ is the critical shear stress for erosion $\left(\mathrm{N} \mathrm{m}^{-2}\right) . M$ is a coefficient quantifying the erosion rate $\left(\mathrm{kg} \mathrm{m}^{-2} \mathrm{~s}^{-1}\right)$. The following formula describes the deposition rate:

$D=C w_{\mathrm{s}}$,

in which $D$ is the deposition rate $\left(\mathrm{kg} \mathrm{m}^{-2} \mathrm{~s}^{-1}\right), C$ is the sediment concentration (depth-averaged) (e.g. Montes et al., $2010)$ and $w_{\mathrm{S}}$ is the fall velocity of suspended solids $\left(\mathrm{m} \mathrm{s}^{-1}\right)$. It is assumed that deposition occurs only if the bed shear stress does not exceed the critical shear stress for deposition, $\tau_{\mathrm{d}}\left(\mathrm{N} \mathrm{m}^{-2}\right)$.

For the description of the soil processes, the model records the bed level changes in vertical direction with time together with the composition of the deposited sediment, according to an adapted version of Hirano's (1971) bed layer model (Blom, 2008). This permits study of the evolution of the vertical stratification of sediment deposits.

\subsection{Hydrodynamic model: setup, calibration and validation}

The 2-D depth-averaged model was built to cover the reservoir area from the dam to El Deim, $30 \mathrm{~km}$ upstream of the end of the reservoir (about $110 \mathrm{~km}$ in total). The reservoir shape is rather complex, as shown in Fig. 2. Consequently, the computational curvilinear grid size is variable, ranging from 25 to $280 \mathrm{~m}$ (Fig. 6). The upstream boundary condition was represented by the daily discharge time series measured at El Deim. The downstream boundary condition was represented by the corresponding water levels measured at Wad Almahi and by the dam outflow discharges.

The selection of the simulation time step depends on several parameters, such as the grid size of the model, the water depth, the required accuracy and the stability of the model during simulation. The Courant number $\left(C_{\mathrm{r}}\right)$ is defined by

$C_{\mathrm{r}}=\frac{\Delta t \sqrt{g h}}{\{\Delta x, \Delta y \cdot\}}$

In general, $C_{\mathrm{r}}$ should not exceed a value of 10 . (Deltares: Delft 3D-Flow User manual, Simulation of Multidimensional Hydrodynamic Flows and Transport Phenomena, Delft, the Netherlands, 38-43, 2010.) For the hydrodynamic model and the selected schematisation of the grid cells, the time step used is $30 \mathrm{~s}$ and the value of $C_{\mathrm{r}}$ varies in space and time. The values of other numerical parameters adopted in the model coincide with the default values of the Delft3D software.

During the model setup phase, inaccuracies due to the large size of the computational grid cells were compensated for by manual adjustments of topographic levels, ensuring that the thalweg elevation in the model is close to the measured one.

The hydrodynamic model was calibrated on the 2009 water levels measured at Famaka, a measuring station located inside the reservoir, about $80 \mathrm{~km}$ upstream of the dam (Fig. 2). The chosen values of the calibration parameters and the closure coefficients for the $k-\varepsilon$ model are given in Table 2. In particular, the bed roughness resulted in a Chézy coefficient of $80 \mathrm{~m}^{1 / 2} \mathrm{~s}^{-1}$. Figure 7 a shows the results of model calibration.

The hydrodynamic model was validated using the daily discharge time series measured at El Deim (upstream open boundary condition), the daily dam outflow (downstream open boundary condition) and the water levels measured at Wad Almahi (inside the reservoir) in 2010.

\subsection{Morphodynamic model: setup, calibration and validation}

The hydrodynamic model was then used to set up the morphodynamic model, with the aim to simulate sediment deposition and erosion inside the reservoir during the two periods 1985-1992 and 1992-2007. The model was calibrated and validated on the measured bed level changes in these two periods derived from the bathymetric data. There were no data available on soil stratification. The hydrodynamic boundary conditions were the time series of monthly inflow and outflow discharges and averaged water levels inside the reservoir.

The morphodynamic computations were excessively timeconsuming due to the large number of computational cells. This large number of cells was inevitable due to the vastness of the reservoir and the complexity of the processes to be simulated, such as 2-D hydrodynamics, bed and suspended load transport, soil erosion and sediment deposition, together with the storing of the bed composition. To limit the duration of each computational run to a couple of weeks, the 
Table 2. The values of physical parameters derived from the calibration process.

\begin{tabular}{ll}
\hline Physical parameter & Calibrated value \\
\hline Spiral flow $-(\beta)$ & $0.5(-)$ \\
Horizontal eddy viscosity & $1.0\left(\mathrm{~m}^{2} \mathrm{~s}^{-1}\right)$ \\
Horizontal eddy diffusivity & $10\left(\mathrm{~m}^{2} \mathrm{~s}^{-1}\right)$ \\
Specific density of sediment & $2650\left(\mathrm{~kg} \mathrm{~m}^{-3}\right)$ \\
Csoil (reference density of hindering settling) & $1600\left(\mathrm{~kg} \mathrm{~m}^{-3}\right)$ \\
$D_{50}$ & $700 \mu \mathrm{m}$ \\
Dry density of sand & $2000\left(\mathrm{~kg} \mathrm{~m}^{-3}\right)$ \\
Dry density of silt (deposited suspended solids) & $1200\left(\mathrm{~kg} \mathrm{~m}^{-3}\right)$ \\
$W_{\mathrm{s}, 0}($ settling velocity of suspended solids) & $0.005\left(\mathrm{~mm} \mathrm{~s}^{-1}\right)$ \\
$\tau_{\mathrm{c}}($ critical shear stress for erosion of silt) & $1.0\left(\mathrm{~N} \mathrm{~m}^{-2}\right)$ \\
$\tau_{\mathrm{d}}($ critical shear stress for deposition of suspended solids) & $1000\left(\mathrm{~N} \mathrm{~m}^{-2}\right)$ \\
$M$ (erosion rate of deposited silt) & $2\left(\mathrm{mg} \mathrm{m}^{-2} \mathrm{~s}^{-1}\right)$ \\
\hline
\end{tabular}

Table 3. Summary of the characteristics of the four trenches.

\begin{tabular}{|c|c|c|c|c|c|c|c|}
\hline $\mathrm{E}^{\mathrm{a}}$ & $\mathrm{N}^{\mathrm{a}}$ & $\begin{array}{l}\text { Trench } \\
\text { depth } \\
(\mathrm{m})\end{array}$ & Location & $\begin{array}{l}\text { Nearest } \\
\text { village }\end{array}$ & $\begin{array}{l}\text { Distance from } \\
\text { main channel } \\
(\mathrm{km})^{\mathrm{b}}\end{array}$ & $\begin{array}{l}\text { Distance } \\
\text { from dam } \\
(\mathrm{km})\end{array}$ & Remarks \\
\hline 650539 & 1280023 & 2.5 & $\begin{array}{l}\text { Area } 2 \\
(\text { trench } 1)\end{array}$ & Ofood & 3.4 & 26 & left bank \\
\hline 650537 & 1280055 & 4.0 & $\begin{array}{l}\text { Area } 2 \\
(\text { trench } 2)\end{array}$ & Ofood & 3.4 & 26 & left bank \\
\hline 653332 & 1284514 & 4.0 & $\begin{array}{l}\text { Area } 2 \\
(\text { trench } 3)\end{array}$ & El Dakhla & 1.3 & 23 & right bank \\
\hline 673117 & 1265608 & 2.5 & $\begin{array}{l}\text { Area } 1 \\
(\text { trench } 4)\end{array}$ & Wad El Mahi & 0.4 & 51 & right bank \\
\hline
\end{tabular}

a These coordinates are in UTM, WGS84, Zone 36 North. ${ }^{\mathrm{b}}$ When reservoir is empty.

morphodynamic model was speeded up using the morphological factor introduced by Roelvink (2006). We adopted a morphological factor equal to 30 to represent the morphological changes occurring in 1 month by simulating one single day (hydrodynamically). This is obtained by multiplying the corresponding morphological changes by a factor of 30 . The approach creates a water balance problem in the reservoir, since the hydrodynamic part could not represent the behaviour of 1 month. To respect the balance, water was added to or subtracted from the reservoir during the computations, which could be done only in a distributed way, to be applied to the wet surface of the reservoir, similar to rain and evaporation. The relation surface elevation was derived from the bathymetric data and then used for this purpose (Fig. 5). This method allowed for the water balance and the water levels in the reservoir to be respected, but not the flow velocity distribution inside the reservoir, which suffered from inaccuracies. These inaccuracies were mainly due to the gradual increase/decrease in water discharge along the reservoir and particularly affected the filling-in and flushing times.

Dredging was implemented as a yearly operation. The upstream input of suspended sediment concentrations during

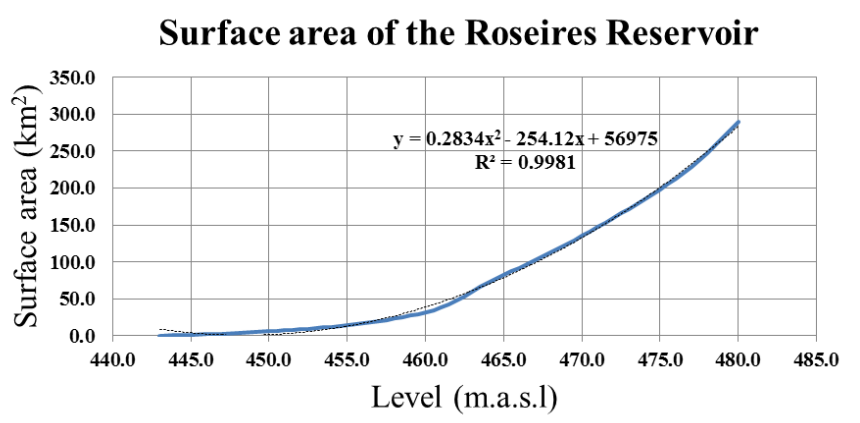

Figure 5. Water surface area in Roseires Reservoir as a function of elevation (irrigation datum). The dotted line represents the trend line used in the study.

high flows was the corresponding averaged values derived from the measured data. Suspended sediment input during the low-flow season was kept constant and equal to the measured one.

The model was calibrated on the period 1985-1992. This period was selected due to the availability of topographical 


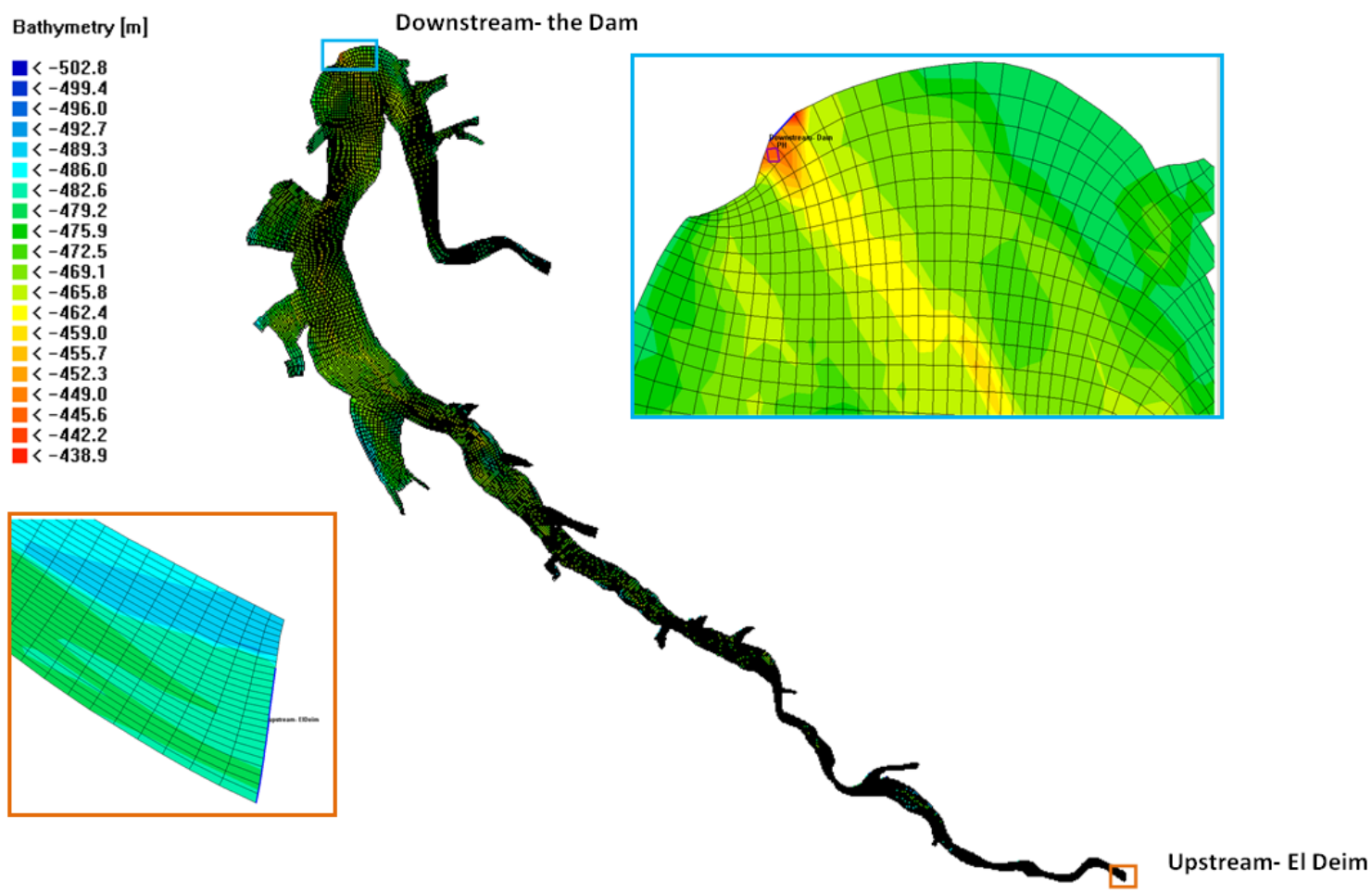

Figure 6. Upstream and downstream boundaries, computational grid and bed elevations in 2009, in m a.s.1. (irrigation datum).

surveys. This means that the model was run for 7 years with the required input data starting from the bed topography measured in 1985. The final result of the model was then compared with the measured topography of 1992 . The model parameters were tuned until the simulated topography was comparable to the measured one in a satisfactory way.

Given the large variety of sediments settling in the reservoir and the necessity to consider only two components (sand and silt), the transport formula for sand with an averaged diameter of $700 \mu \mathrm{m}$, the fall velocity, the critical shear stress for erosion, and the erosion speed of fine suspended solids were all used as calibration parameters (Table 2).

The transport formula that gave the best results for the sand component was van Rijn's (1984). The optimised fall velocity of the fine suspended solids resulted in $0.005 \mathrm{~mm} \mathrm{~s}^{-1}$ and the critical shear stress for the erosion of deposited silt in $1 \mathrm{~N} \mathrm{~m}^{-2}$. For bed shear stresses above this value, the bed of the reservoir eroded with an erosion rate of $2 \mathrm{mg} \mathrm{m}^{-2} \mathrm{~s}^{-1}$. In natural systems, the erosion rate is a function of bed density (consolidation) and bed shear stress. However, consolidation of sediment deposits is not taken into account in the model. This means that all densities are prescribed initially and kept constant in time. We applied a dry-bed density of $1200 \mathrm{~kg} \mathrm{~m}^{-3}$ for the deposited silt (porosity $=0.55$ ) and of $2000 \mathrm{~kg} \mathrm{~m}^{-3}$ for sand (porosity $=0.25$ ). In the model, the value of the dry density does not have any influence on the erosion rate, but it has some influence on the bed-level changes (the smaller the imposed dry density is, the larger the change in volume due to the presence of the pores between the sediment particles).

The critical shear stress for deposition resulted in $1000 \mathrm{~N} \mathrm{~m}^{-2}$. Below this value, any particle was free to deposit according to its fall velocity and depending on the computed bed shear stress.

Figure 8 shows the measured and simulated cross sections 18 and 19B $(10.8 \mathrm{~km}$ and $15.4 \mathrm{~km}$ upstream of the dam, respectively). The model does not provide accurate results at this level of detail. Computed section 18 shows that the model fails to simulate the main channel shift (compare measured and simulated 1992 topography). The same applies to section 19B. This might be due to the relatively large grid size and the distance of the measured cross sections (2-5 km), which does not allow for proper reproduction of curved flow effects inside the main channel.

Figure 9a shows the measured difference in bed topography and Fig. 9b the simulated difference for 1992-1985. In the figures, the ellipses show the areas for which the bed topography of 1985 and 1992, being unknown, was made equal to the bed topography of 2009. These areas should therefore not be considered, although they might have influenced the bed level changes in other areas. By comparing simulated with measured differences in bed elevation, it can be observed that the upstream part (1), subjected to deposition, has the same deposition pattern, but a smaller deposited volume, in the simulation. Some eroded areas (2) can also be recog- 


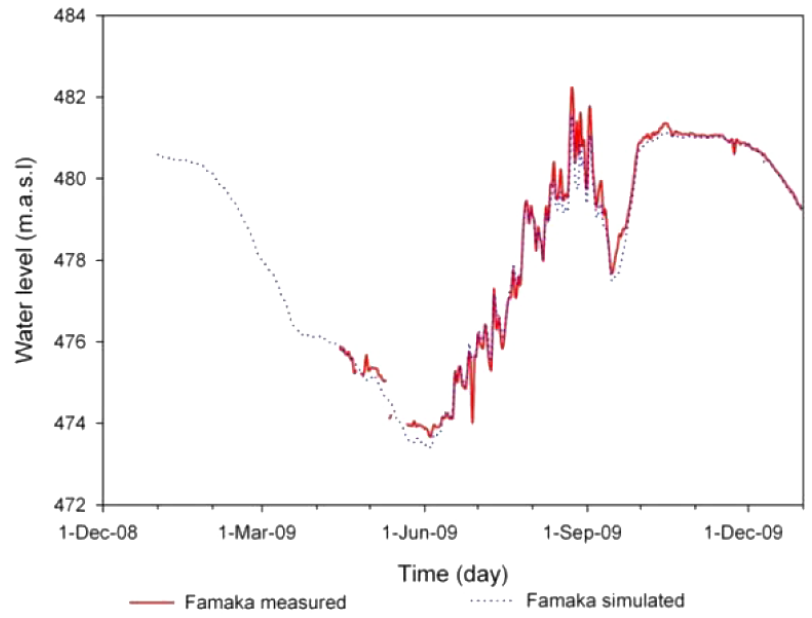

(a)

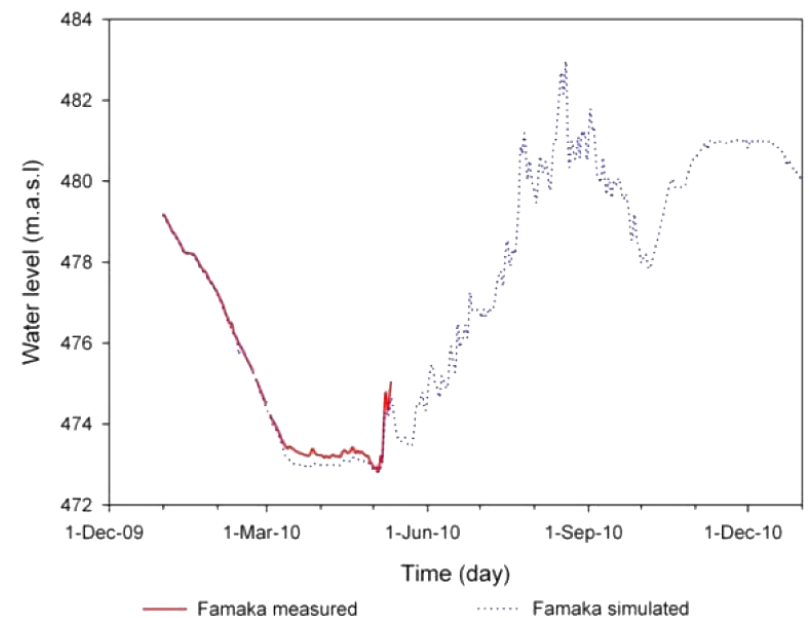

(b)

Figure 7. Results of hydraulic model calibration (a) and validation (b): computed vs. measured water levels at Famaka (location in Fig. 2). Levels in ma.s.l. (irrigation datum).
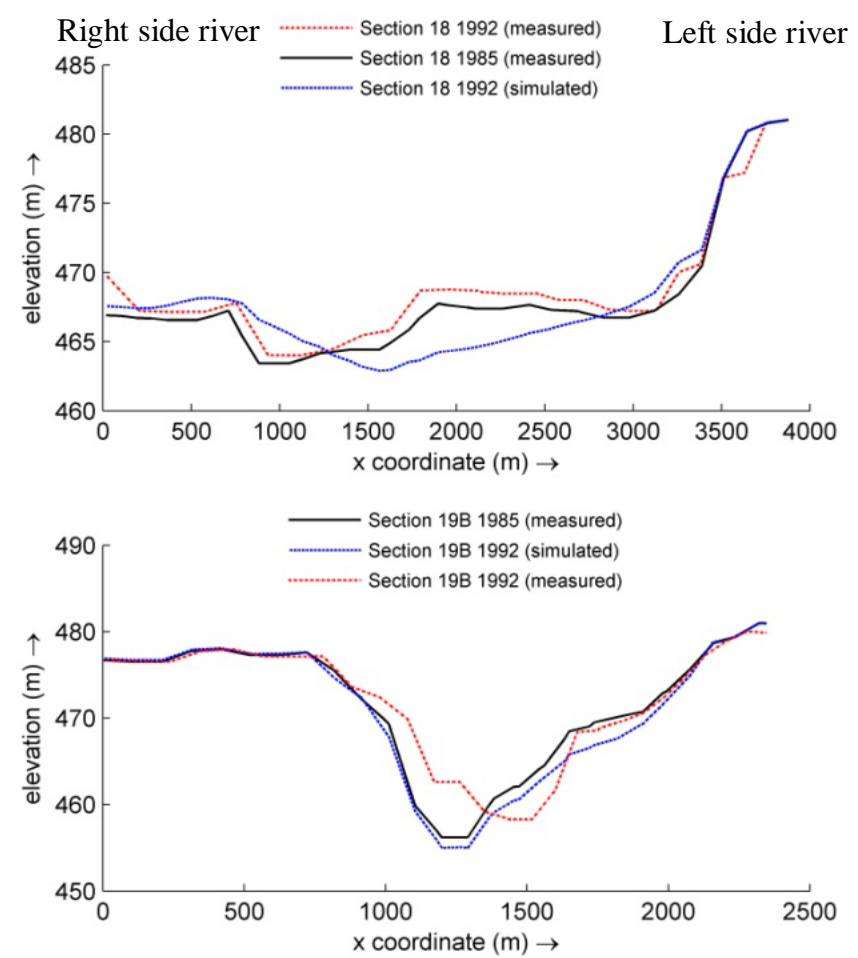

Figure 8. Cross sections 18 and 19B seen from downstream. Measured 1985 and 1992 bed elevations and simulated 1992 bed elevation. Cross sections 18 and $19 \mathrm{~B}$ are located 10.8 and $15.4 \mathrm{~km}$ upstream of the dam, respectively.

nised in the simulation, especially the area closer to the dam and the narrow area more upstream.

The total computed cumulative deposited volume of sediment in the period $1985-1992$ is $188 \times 10^{6} \mathrm{~m}^{3}$, which is $29 \%$ larger than the measured volume $\left(146 \times 10^{6} \mathrm{~m}^{3}\right.$, from Table 1). Based on this we considered the results of the calibration to be satisfactory.

The model was then validated on the developments occurred in the next 15 years, from the end of 1992 to the end of 2007. The runs started with the bed topography of 1992. The results representing the bed topography after 15 years were compared to the measured bed levels in 2007. The simulated morphological changes inside Roseires Reservoir show significantly higher deposition rates than the measured ones. The computed total cumulative sediment deposit in this period is $567 \times 10^{6} \mathrm{~m}^{3}$, which is more than double that of the measured $238 \times 10^{6} \mathrm{~m}^{3}$ (Table 1). To analyse the implications of this overestimation at the cross-sectional scale, we compare the measured and simulated sections 18 and 19B in Fig. 10. The simulated section 18 in 2007 shows a deposition of $2-2.5 \mathrm{~m}$ with respect to section 18 in 1992, which is larger than the measured one. In particular, the model does not correctly reproduce the main channel shift inside the reservoir at section 19B.

We believe that the unavailability of good field data reflects on the model accuracy and output reliability. In this study, data were not available in sufficient detail and were limited in terms of quality and extent. For instance, the cross sections measured during the bathymetric surveys of 2009 are 2 to $5 \mathrm{~km}$ far from each other and the surveys do not cover the entire length of the reservoir. This creates inaccuracy in preparing the reservoir bed topography considering the length of Roseires Reservoir $(80 \mathrm{~km})$ and its meandering shape. The relatively large grid size adopted in the model adds to this. The combination of poor data and model accuracy resulted in the smoothing-down of the bed topography differences, which is particularly impacting on the simulated 
(a) Measured difference (1992-1985) of bed topography (m)

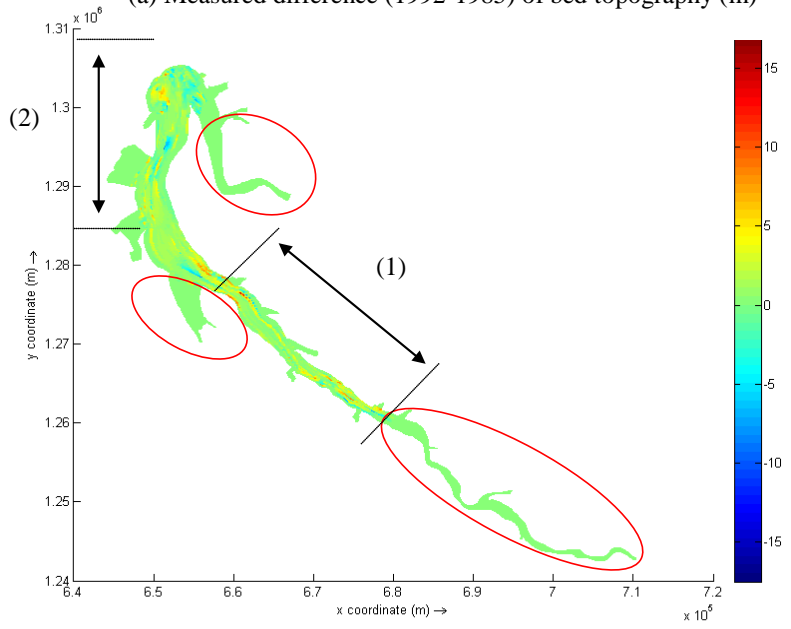

(b) Simulated difference (1992-1985) of bed topography (m)

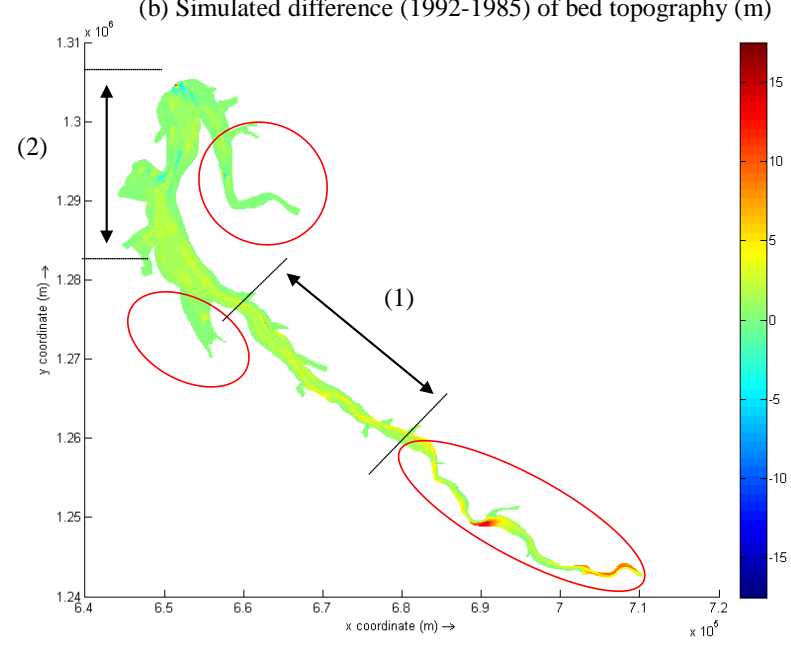

Figure 9. Comparison between the difference in measured bed topography for 1992-1985 and the model cumulative erosion and deposition during the 7-year model run.

channel inside the reservoir. The simulated flow velocity is more uniform than in reality and remarkably lower in the channel. Lower velocity in the channel results in excessive sedimentation of the sand component in the upstream part of the reservoir, a lack of sand in the deposits more downstream, higher deposition rates of the silt component, and less efficient sediment flushing in the model than in reality. Since the channel becomes more important with time as reservoir sedimentation progresses, this effect is more important for the validation period than for the calibration period. This might explain the increased overestimation of sediment deposition for the validation period.

The discrepancies between model and measurements could also be caused by an overestimation of the sediment inputs. In particular, the suspended solids concentrations for the 2000s seem to be overestimated by the adopted averaged value.
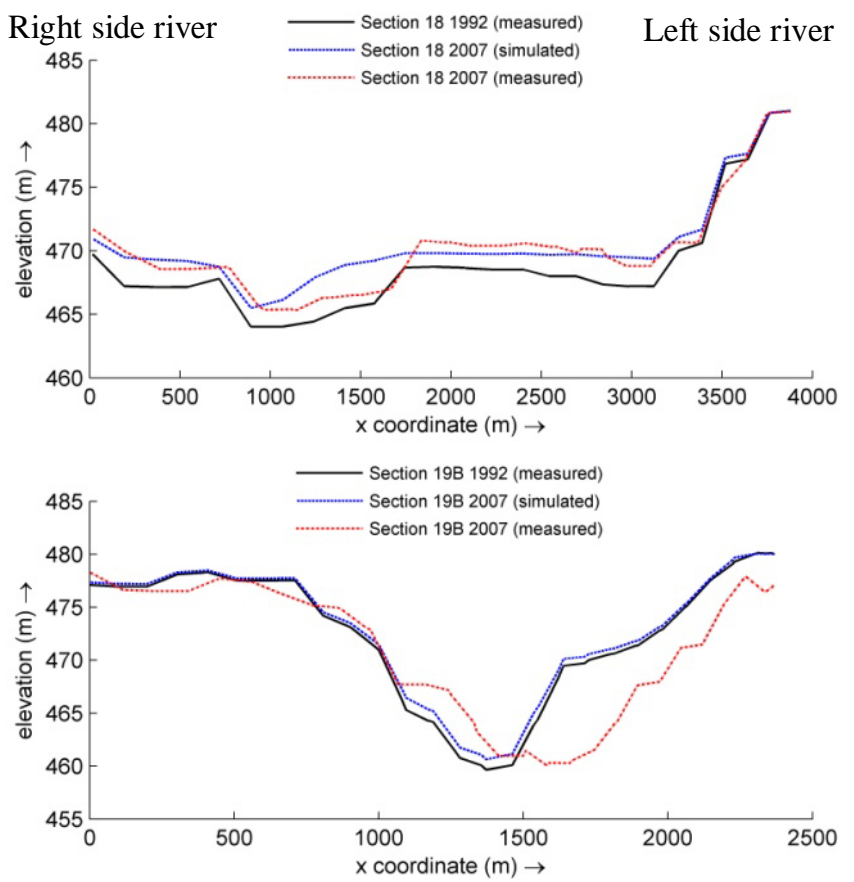

Figure 10. Cross sections 18 and 19B seen from downstream. Measured 1992 and 2007 bed elevations and simulated 2007 bed elevation. Cross sections 18 and 19B are located 10.8 and $15.4 \mathrm{~km}$ upstream of the dam, respectively.

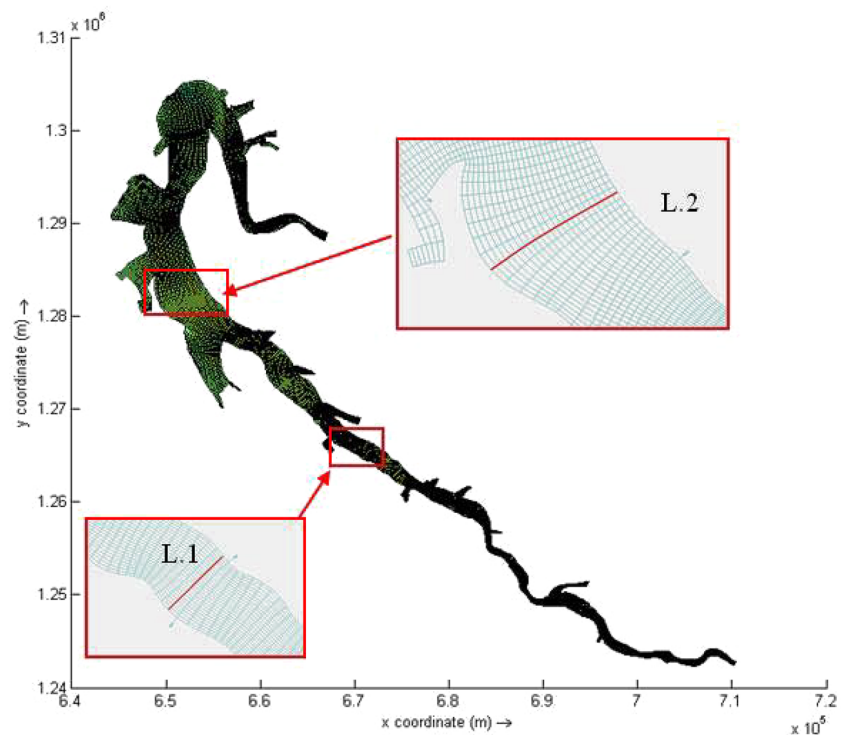

Figure 11. Selected coring areas (L1 and L2).

\section{Identification of promising coring areas}

One important goal of the modelling study was the identification of the most promising sampling locations to study soil stratification. These locations should fulfil the following conditions: (1) easy accessibility; (2) absence of bed erosion; (3) 


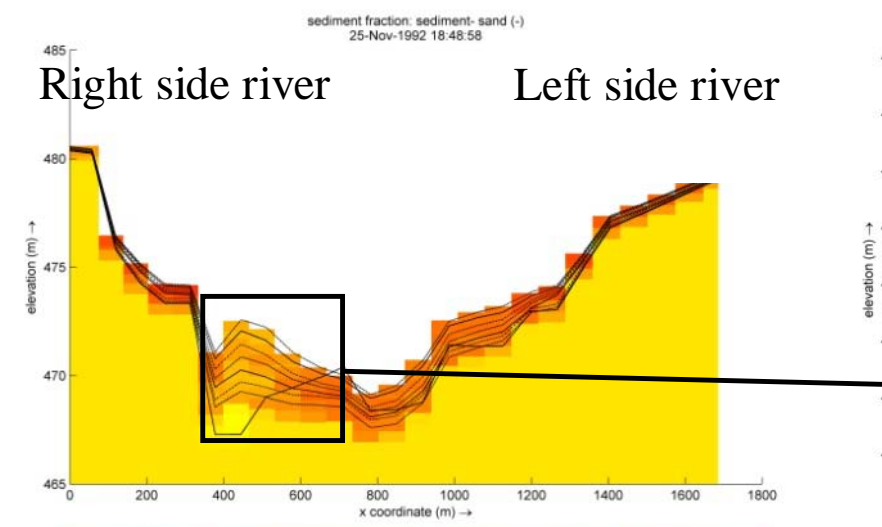

(a)
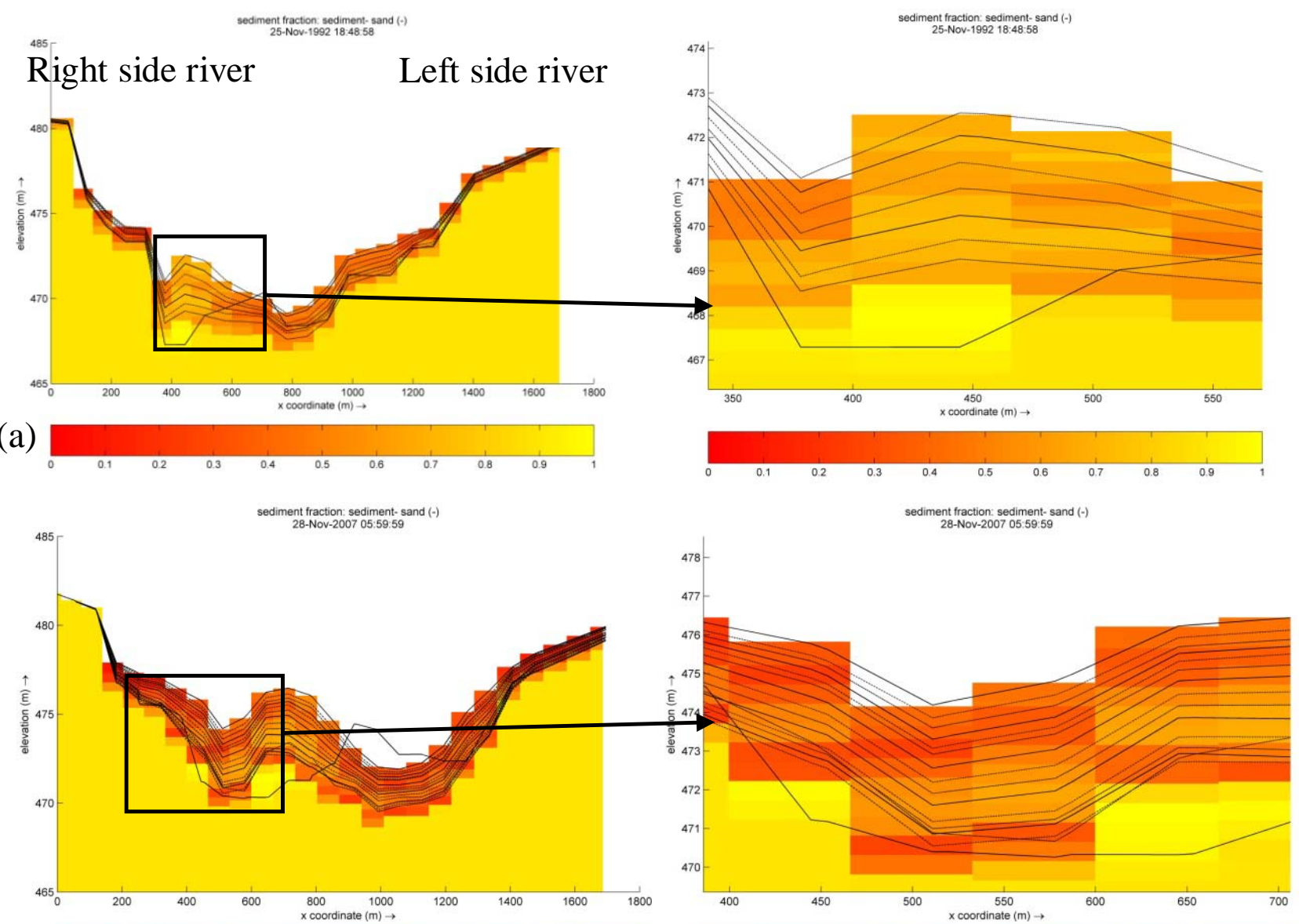

(b)
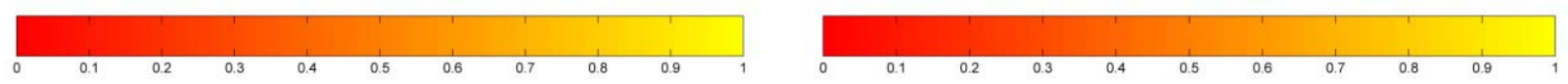

Figure 12. Vertical profiles of bed composition in Area 1 seen from downstream. Left: entire cross section. Right: zoomed areas. (a) Period 1985-1992; (b) period 1992-2007. Colour bar: sand content from 0 (red) to $100 \%$ (yellow).

absence of bar movement, destroying soil stratification; and (4) recognisable soil stratification.

Two areas were selected for the sampling, as shown in Fig. 11, based on the absence of erosion and bar migration in the model outputs.

Area 1. Figure 12 shows the vertical profiles of deposition at Area 1. In Fig. 12a, the solid lines represent the final bed levels of 1985, 1988 and 1991. In Fig. 12b, the solid lines represent the final bed levels of 1992, 1995, 1998, 2001, 2004 and 2007. In areas characterised by the absence of bed erosion, the lowest solid line represents the first year, whereas the top line represents the final year of the computation. In Area 1, according to the model, deposition always occurs at the right side of the reservoir, from 0 to $250 \mathrm{~m}$ from the right bank. Erosion occurs due to channel shift in the middle of the reservoir. The last $200 \mathrm{~m}$ on the left side of the reservoir, from 1500 to $1700 \mathrm{~m}$, is again characterised by deposition only. The dominant deposited sediment in 1986 (dry year) is sand. Sand content is higher in the period 1985-1992 (Fig. 12a) than in the following 15 years (Fig. 12b). The general trend in the years 1989, 1990, 1991 and 1992 is deposition of coarser sediment in the deepest area (main channel). Deposition and stratification occur at the sides of the reservoir. These areas become dry at the end of the dry season and are always characterised by deposition, which makes them promising coring areas.

Area 2. According to the model, the left side of this section is subject to deposition only, for approximately $3 \mathrm{~km}$. In this area, the reservoir is relatively wide. Most of the sediment deposited in this section is silt with only a minor percentage of sand. Stratification is less visible or absent, and for this reason Area 2 seems less suitable than Area 1 for coring.

\section{Model verification based on soil stratification data}

A subsequent field campaign was carried out in summer 2012 in the areas identified by the model. We visited those areas during the rainy season, when the reservoir gates are 


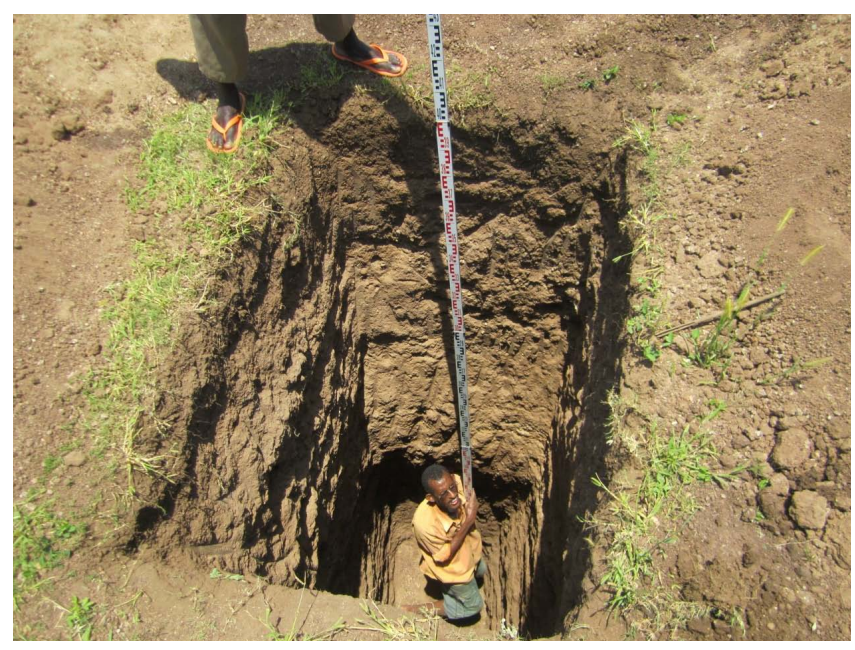

Figure 13. Trench excavation inside Roseires Reservoir.

open and the water level is the lowest. This allowed us to reach zones that are normally submerged. The central channel, however, was not reachable and sampling was carried out only in the areas that had become dry on the right or left bank, as shown in Table 3. In Area 1, about $45 \mathrm{~km}$ upstream of the dam, the reservoir width is $1.5 \mathrm{~km}$, whereas in Area 2, $25 \mathrm{~km}$ upstream of the dam, the reservoir width is $4 \mathrm{~km}$. The larger width allowed for a wider transect to be covered, but, due to a number of logistic constraints during the field campaign, we were able to excavate only four trenches. Three trenches were excavated in Area 2 and a fourth trench was excavated in Area 1. The characteristics and locations of the four trenches are summarised in Table 2 and shown in Fig. 13.

Sampling in these areas allowed for study of the granulometric characteristics of the deposited sediment and validation of the model results in terms of soil stratification. The analysis of the sediment showed that, at least in the selected areas, the reservoir soil is indeed stratified. However, the layers are not distinguishable from alternations of sand and silt, but they are from alternations of coarse and fine sand. These alternations are visible from the vertical profile of the $D_{90}$ of the sediment (Fig. 14). This important difference between model and field data can be attributed to systematic underestimation of the flow velocities inside the reservoir, particularly inside the channel, where most sand is transported downstream. This is most probably due to the difficulty of guaranteeing the water balance (due to the adoption of a morphological factor) and reproducing the channel excavated within the reservoir soil (due to low model and data resolution). Both the morphological factor and the poor resolution were inevitable, though, given the long simulation times (each computation had a duration of weeks) and the data available for the study. Underestimation of flow velocity results in higher sedimentation rates and in sand being deposited in the upstream part of the reservoir (delta formation: Fan and Morris, 1992; Kostic and Parker, 2003a, b).

No signs of soil erosion could be detected from the analysis of the trenches. This means that the model was successful in identifying the areas in which no soil erosion has occurred.

Sediments are believed to become finer farther from the central channel in the transverse direction, where the flow velocity (during high water) is lower, and in downstream direction, due to selective deposition in the reservoir, the coarser material being deposited in the upper parts. However, clear sediment sorting trends cannot be observed from the field data, neither in the transverse direction nor in the longitudinal direction. We believe that this is due to the limited number of excavated trenches. Sedimentation strongly depends on local hydrodynamic conditions, and for this a general sorting trend can only be detected with a large number of spatially distributed coring locations.

\section{Conclusions}

Two promising coring areas inside Roseires Reservoir were selected by combining bathymetric data analysis with the results of a 2-D morphodynamic model including horizontal and vertical sorting. The model allowed for study of the contribution of two sediment types, sand and silt, both transported by the Blue Nile into the reservoir. The model setup was based on the hypothesis that sand is deposited during high flows, whereas fine material, mainly originating from upper catchment erosion, is deposited during low-flow periods. This would create soil stratification inside the reservoir, allowing for the recognition of specific wet or dry years. The model, with recorded bed level changes and soil composition in vertical direction, shows vertical stratification in the reservoir soil at several cross sections. Two of these cross sections were selected as the best areas for analysing the sedimentation process in the reservoir.

The results of the subsequent field campaign carried out in the summer 2012 show clear soil stratification at the four trenches excavated in the selected areas, but layers are mainly distinguishable from the presence of coarse and fine sand rather than from alternations of sand and silt. Coarse sand was mainly deposited there during distinguishable wet years, which allowed for the progression of sediment deposition in the reservoir to be recognised from the collected soil data.

Sand appears to be transported and deposited in the reservoir much further downstream than the model predicts. This can be explained by systematic underestimation of the flow velocity in the reservoir during high flows. The cause seems to lie in the adoption of a morphological factor to speed up the computations leading to inaccuracies in the flow velocity estimation and in the poor resolution of data and model, resulting in a more uniform bed topography and flow velocity, leading to lower velocity in the central channel, where sand is transported downstream. 


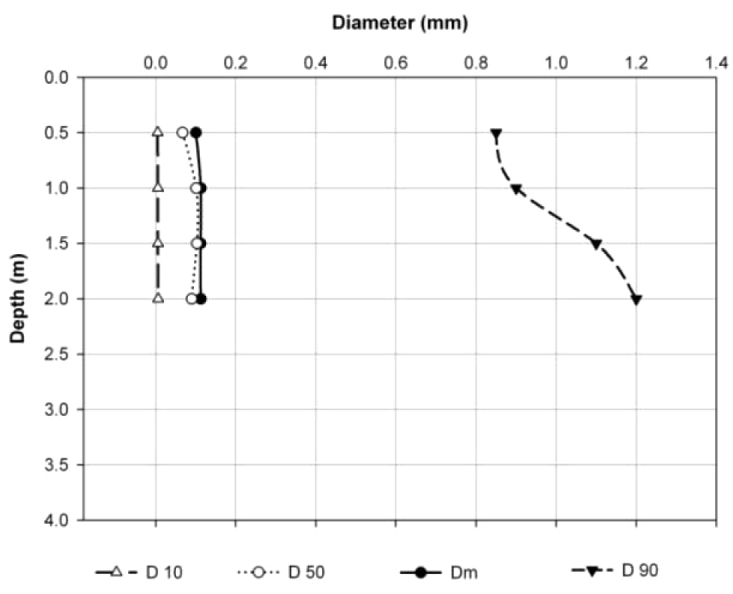

Trench (1)(Area 2, $3.4 \mathrm{~km}$ from channel)

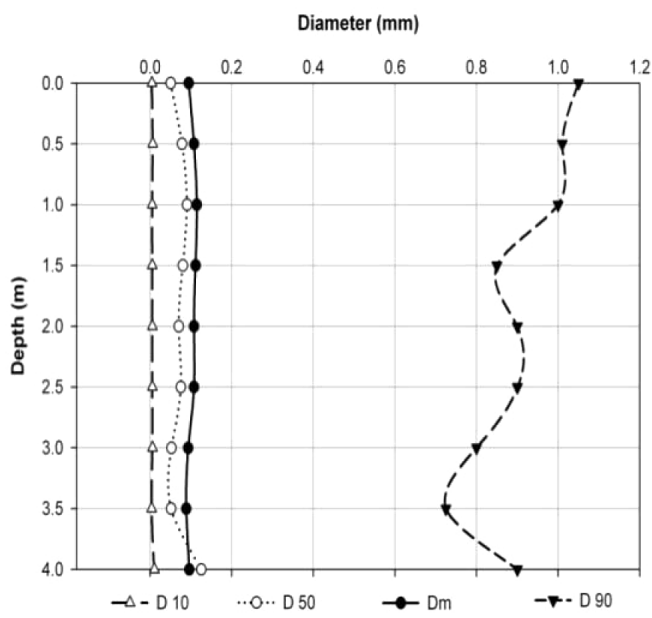

Trench (3) (Area 2, $1.3 \mathrm{~km}$ from channel)

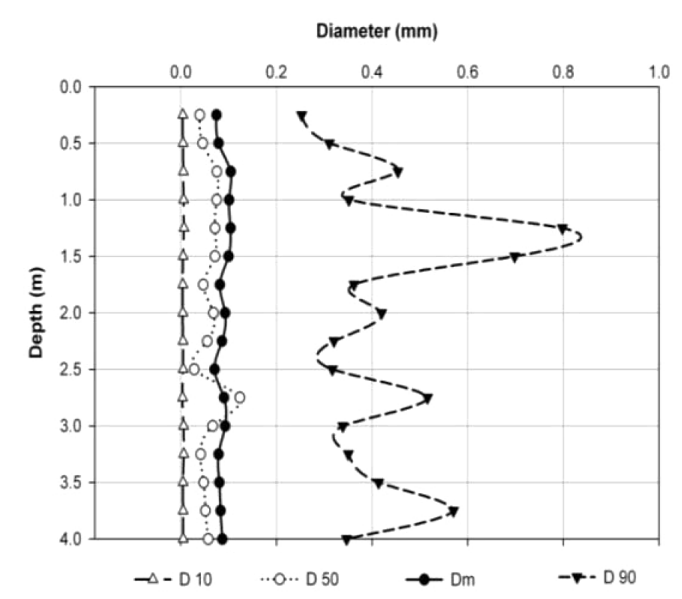

Trench (2)(Area 2, $3.4 \mathrm{~km}$ from channel)

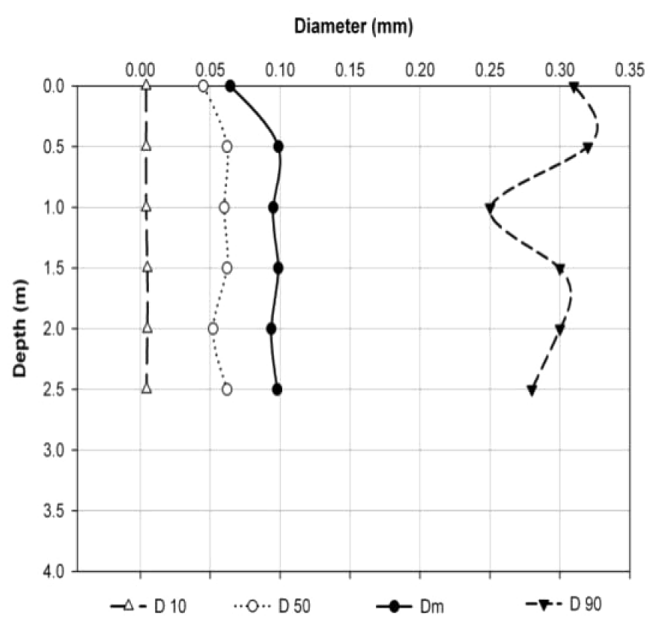

Trench (4) (Area 1, $0.4 \mathrm{~km}$ from channel)

Figure 14. Soil stratification at the four trenches.

The discrepancies between model and measurements could also be due to an overestimation of the sediment inputs. In particular, the suspended solids concentrations for the 2000s seem to be overestimated by the adopted averaged value. For this reason, suspended solids concentrations should be carefully measured in the future. In particular, more measurements are required during the low-water season, at least for modelling purposes.

To implement the model in a more reliable way in the future, it is suggested to reduce its cell size, to reduce or eliminate the morphological factor, and to perform more accurate bathymetric surveys, preferably with a side-scan sonar. If computational cell size reduction is not feasible, due to unacceptably long computational times, the suggestion is to nest the model with smaller cells in the central area occupied by the channel.
Notwithstanding these limitations, the model allowed for two appropriated coring areas to be recognised, where the soil had never been eroded and was indeed stratified. Moreover, the model allowed for analysis of the sedimentation process in the reservoir with a level of detail that would not have been possible by solely analysing the available data, allowing for data correction at several locations where the horizontal coordinates were uncertain.

Acknowledgements. The study was carried out as a project within a larger research programme called "In search of sustainable catchments and basin-wide solidarities in the Blue Nile River Basin", funded by the Foundation for the Advancement of Tropical Research (WOTRO) of the Netherlands Organisation for Scientific Research (NWO) and UNESCO-IHE. The authors are grateful to the Ministry of Water Resources and Electricity, Hydraulic Research Station, Wad Madani, and the Dam Implementation Unit, 
Khartoum, Sudan, for providing data free of charge. The authors wish to thank Mick van der Wegen and Kees Sloff for their helpful advice in the modelling phase. The authors wish to thank Mohamed Osman and Yasir Abo ElGasim for their helpful support during the field work.

Edited by: F. Metivier

\section{References}

AbdAlla, M. B. and Elnoor, K.: Hydrographic Survey of Roseires Reservoir, Ministry of Irrigation and Water Resources, Khartoum, Sudan, Khartoum, 2007.

Ahmed, A. A. and Ismail, U. H. A. E.: Sediment in the Nile River system. Consultancy Study requested by UNESCO and International Sediment Initiative (ISI), Khartoum, Sudan, 2008.

Ahmed, A. A., Ibrahim, S. A. S., Ogembo, O., Babikir, I. A. A., Fadul, H. M., Ibrahim, A. A., and Crosato, A.: Nile River bank erosion and protection, Hydraulic Research Institute, Cairo, Egypt, 2010.

Ali, Y. S. A.: The impact of soil erosion in the Upper Blue Nile on downstream reservoir sedimentation, Ph.D. Thesis, Technical University of Delft, the Netherlands, ISBN 978-1-138-027428 (Taylor \& Francis Group), p. 17, 2014.

Annandale, G. W.: Reseroir Sedimentation, Elsevier Science Publishers B. V., New York, 1987.

Ariathurai, R. and Arulanandan, K.: Erosion rates of cohesive soils, J. Hydraul. Divis., 104, 279-283, 1978.

Awulachew, S. B., McCartney, M., Steenhuis, T. S., and Ahmed, A. A.: A review of hydrology, sediment and water resource use in the Blue Nile Basin, International Water Management Institute, Addis Ababa, Ethiopia, 2008.

Ayalew, L. and Yamagishi, H.: Slope failures in the Blue Nile basin, as seen from landscape evolution perspective, Geomorphology, 57, 95-116, 2004.

Bagnold, R.: An approach to the sediment transport problem from general physics: US Geol. Survey Professional Paper 422-I, Washington, 1-37, 1966.

Bashar, K. E. and Eltayeb, A.: Sediment Accumulation in Roseires Reservoir, Nile Bas. Water Sci. Engin. J., 3, 46-55, 2010.

Bashar, K. E., ElTahir, E. T. O., Fattah, S. A., Ali, A. S., Musnad, M., Siyam, A. M., and Crosato, A.: Nile Basin Reservoir Sedimentation Prediction and Mitigation, Hydraul. Res. Instit., Cairo, Egypt, 2010.

Billi, P. and el Badri Ali, O.: Sediment transport of the Blue Nile at Khartoum, Quaternary Internat., 226, 12-22, 2010.

Blanckaert, K., Glasson, L., Jagers, H. R. A., and Sloff, C. J.: Quasi-3D simulation of flow in sharp open-channel bends with equilibrium bed topography, in: proc. RCEM 2003, 1-5 September 2003, Barcelona, Spain, edietd by: Sanchez-Arcilla, A. and Bateman, A., IAHR, Vol. I, 652-663, 2003.

Blom, A.: Different approaches to handling vertical and streamwise sorting in modelling river morphodynamics, Water Resour. Res., 44, W03415, doi:10.1029/2006WR005474,2008.

Borland, W. M.: Reservoir Sedimentation, River Mechanics, edited by: Shen, H. W., Water Resources Publications, 1-38, ,1971.

Boussinesq, J.: Theorie analytique de la chaleur. Gautier Villars, 2, Paris, 1903 (in French).
Bowonder, B., Ramana, K. V., and Rao, T. H.: Sedimentation of reservoirs in India, Land Use Policy, 2, 148-154, 1985.

Chang, H. H.: Fluvial Hydraulics of Deltas and Alluvial Fans, J. Hydraul. Div., ASCE, 108, HY 11, 1982.

Chang, H. H. and Hill, C. H.: Minimum stream power for rivers and deltas, J. Hydraul. Div., ASCE, 97, HY6, 1977.

Churchill, M. A.: Disscussion of Analysis and use of reservoir sedimentation in: Federal Inter-Agency Sedimentation Conference, edited by: Gottschalk, L. C., Washington, DC, 139-140, 1948.

Cristofano, E.: Area increment method of distributing sediment in a reservoir, US Bureau of Reclamation, Albuquerque, New Mexico, 1953.

DEMAS (Dredging, Engineering and Management Studies): Roseires Reservoir Survey - Blue Nile, Ministry of Irrigation and Hydropower, Khartoum, 1985.

De Vente, J., Poesen, J., and Verstraeten, G.: The application of semi-quantitative methods and reservoir sedimentation rates for the prediction of basin sediment yield in Spain, J. Hydrol., 305, 63-86, 2005.

Duquennois, H.: New methods of sediment control in reservoirs, Water Power, 174-180, 1956.

Engelund, F. and Hansen, E.: A Monograph on Sediment Transport in Alluvial Streams, TechniskVorlaq, Copenhagen, Denmark, 1967.

Fan, J., and Morris, G.: Reservoir sedimentation - Part I: Delta and density current deposits, J. Hydraul. Engin., ASCE, 118, 354369, 1992.

Garg, V. and Jothiprakash, V.: Estimation of useful life of a reservoir using sediment trap efficiency, J. Spatial Hydrol., 8, 1-14, 2008.

Gismalla, Y. A.: Bathymwtric Survey of Roseires Reservoir, Ministry of Irrigation and Water Resources, Wad-Madani (Sudan), 1993.

Gottschalk, L.: Reservoir sedimentation, Handbook of Applied Hydrology, New York, McGraw-Hill, 17, 1964.

Hama, N. H. R.: Exploratory Study of Reservoir Sedimentation by 2-D and 3-D Mathematical Modelling, UNESCO-IHE, Delft, the Netherlands, 1-22, 2006.

Hirano, M.: River bed degradation with armouring, Trans. Japan Soc. Civil Engin., 3, 194-195, 1971.

Hotchkiss, R. H. and Parker, G.: Shock fitting of aggradational profiles due to backwater, J. Hydraul. Engin., 117, 1129-1144, 1991.

$\mathrm{Hu}, \mathrm{C}$. , Guo, Q., Chen, J., and Cao, W.: Applications of numerical simulation to the sedimentation in the Sanmenxia reservoir and the Lower Yellow River, Internat. J. Environ. Pollut., 42, 148$165,2010$.

Hussein, A. S., Bashar, K. E., ElTahir, E. T. O., Fattah, S. A., and Siyam, A. M.: Reservoir Sedimentation, Nile Basin Capacity Building Network (NBCBN), Khartoum, Sudan, 2005.

Ikeda, S.: Lateral bed load transport on side slopes, J. Hydraul. Div., 108, 1369-1373, 1982.

Kostic, S. and Parker, G.: Progradational sand-mud deltas in lakes and reservoirs - Part 1: Theory and numerical model, J. Hydraul. Res., 41, 127-140, 2003a.

Kostic, S. and Parker, G.: Progradational sand-mud deltas in lakes and reservoirs - Part 2: Experiment and numerical simulation, J. Hydraul. Res., 41, 141-152, 2003 b.

Lesser, G. R., Roelvink, J. A., van Kester, J. A. T. M., and Stelling, G. S.: Development and validation of a three-dimensional morphological model, Coastal Engineering, 51, 883-915, 2004. 
Mahmood, K.: Reservoir Sedimentation: Impact, Extent and Mitigation. World Bank, Technical Paper Number, Washington, DC, 71, 1987.

Meyer-Peter, E. and Müller, R.: Formulas for bed load transport, in: Proceedings of the 2nd IAHR Congress, Stockholm, Sweden, 2, 39-64, 1948.

Montes, A. A., Crosato, A., and Middelkoop, H.: Reconstructing the early 19th century Waal River by means of a 2-D physics-based numerical model, Hydrological processes, Wily InterScience, 24, 1-15, doi:10.1002/hyp.7804, 2010.

Morris, G. L. and Fan, J.:Reservoir Sedimentation Handbook, McGraw-Hill Book Co., New York, 784 pp., 2009.

Omer A. Y. A.: Sedimentation of sand and silt in Roseires Reservoir: vertical and horizontal sorting with time, MSc thesis (WSEHERBD.11.08), UNESCO-IHE, Delft, the Netherlands, 2011.

Partheniades, E.: A summary of the present knowledge of the behavior of fine sediments in estuaries, Technical Note no. 8, Hydrodynamics Lab, Massachusetts Institute of Technology, Cambridge, MA, June, 1964.
Rãdoane, M. and Rãdoane, N.: Dams, sediment sources and reservoir silting in Romania, Geomorphology, 71, 112-125, 2005.

Roelvink, J. A.: Coastal morphodynamic evolution techniques, J. Coast. Engin., 53, 177-187, 2006.

Sloff, C. J.: Sedimentation in reservoirs, Ph.D. Thesis, Technical University of Delft, the Netherlands, (also in: Communications on Hydraulic and Geotechnical Engineering, Technical University of Delft, Report 97-1, ISBN 90-9010530-1), p. 269, 1997.

Toniolo, H. and Parker, G.: 1-D Numerical modeling of reservoir sedimentation, in: IAHR Symposium on River, Coastal and Estuarine Morphodynamics, Barcelona, Spain, 457-468, 2003.

Vanoni, V. A.: Sedimentation engineering, ASCE, Reston, Virginia, 2006.

The World Commission Dams_W.C.D: Dams and development, A New Framework for Decision-Making, Earthscan Publication Ltd, London, UK, 356 pp., 2000.

White, R.: Review of sedimentation in reservoirs, Evacuation of sediments from reservoirs, Thomas Telford, London, United Kingdom, 17-36, 2001. 